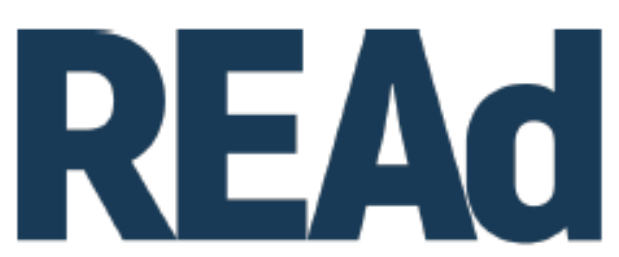

Revista Eletrônica de Administração

\title{
FROM PRACTICE TO THEORY: REFLECTIONS ON THE ORGANIZATION OF SOCIAL MOVEMENTS AND POPULAR STRUGGLES ${ }^{1}$
}

\author{
Maria Ceci Misoczky ${ }^{2}$ \\ Rafael Kruter Flores ${ }^{3}$
}

http://dx.doi.org/10.1590/1413-2311.277.92288

\begin{abstract}
This paper argues for an explicit materialist ontology to study social movements and popular struggles that oppose and confront the capitalist social order. Taking into consideration that differences between theories or theoretical systems should be discussed at the ontological dimension, not merely at the epistemological, empirical or logic-formal, we address the differences between the conventional set of Social Movement Theories, the post-Marxist approach, and an alternative approach that dialogues with those engaged in contemporary struggles, through the ontology of social being formulated by György Lukács. These constitute the first part of this paper, which aims to present our ontological, theoretical and methodological positions. In the second part, we offer some theoretical reflection on the themes provided by the activists in their actions and debates, in dialogue with propositions from intellectuals who engaged with social movements and/or oriented their work to oppose the system of capital.
\end{abstract}

Keywords: Social Movements. Ontology. Popular Struggles. Resistance.

\footnotetext{
${ }^{1}$ Recebido em 30/12/2019, aceito em 9/3/2020.

${ }^{2}$ Universidade Federal do Rio Grande do Sul - Programa de Pós-Graduação em Administração (PPGA); Porto Alegre -RS. (Brasil); https://orcid.org/0000-0003-2020-5882; maria.ceci@ufrgs.br

${ }^{3}$ Universidade Federal do Rio Grande do Sul - Programa de Pós-Graduação em Administração (PPGA); Porto Alegre -RS. (Brasil); https://orcid.org/0000-0003-4280-2231; rafael.flores@ufrgs.br

(ㄷ) $(1) \Theta\left(\right.$ REAd | Porto Alegre - Vol. 26 - N. ${ }^{\circ} 1$ - Janeiro / Abril 2020 - p. 18-48.
} 


\section{DA PRÁTICA À TEORIA: REFLEXÕES SOBRE A ORGANIZAÇÃO DE MOVIMENTOS SOCIAIS E LUTAS POPULARES}

Este artigo argumenta por uma ontologia materialista explícita para estudar movimentos sociais e lutas populares que se opõe e confrontam a ordem social do capital. Levando em consideração que as diferenças entre teorias ou sistemas teóricos devem ser discutidas na dimensão ontológica, não meramente na epistemológica, empírica ou lógico-formal, abordamos as diferenças entre o conjunto convencional de Teorias Sobre Movimentos Sociais, a abordagem Pós-Marxista, e uma abordagem alternativa que dialoga com aqueles engajados em lutas contemporâneas, através da ontologia do ser social formulada por György Lukács. Estas formam a primeira parte do texto, que visa apresentar nossas posições ontológicas, teóricas e metodológicas. $\mathrm{Na}$ segunda parte, oferecemos algumas reflexões teóricas sobre temas emergentes nas ações e debates de ativistas, em diálogo com proposições de intelectuais que se engajaram com movimentos sociais e/ou orientaram seu trabalho para se opor ao sistema do capital.

Palavras-chave: Movimentos Sociais. Ontologia. Lutas Populares. Resistência

\section{DESDE LA PRÁCTICA HACÍA LA TEORÍA: REFLEXIONES SOBRE LA ORGANIZACIÓN DE MOVIMIENTOS SOCIALES Y LUCHAS POPULARES}

Este artículo argumenta por una ontología materialista explícita para estudiar movimientos sociales y luchas populares que se oponen y confrontan el orden social del capital. Tomando en consideración que las diferencias entre teorías o sistemas teóricos deben ser discutidas en la dimensión ontológica, abordamos las diferencias entre el conjunto convencional de Teorías Sobre Movimientos Sociales, el abordaje Post-Marxista y un abordaje alternativo que dialoga con aquellos involucrados en luchas contemporáneas, por medio de la ontología del ser social formulada por György Lukács. Estas constituyen la primera parte del texto, que visa presentar nuestras posiciones ontológicas, teóricas y metodológicas. En la segunda parte, ofrecemos algunas reflexiones teóricas sobre temas que nos fueron indicados por los activistas en sus acciones y debates, en diálogo con proposiciones de intelectuales que se involucraran con movimientos sociales y/o desarrollaran su trabajo en oposición al sistema del capital. 
Palabras clave: Movimientos Sociales. Ontología. Luchas Populares. Resistencia.

The study of social movements (SMs) in the field of Organization Studies (OS) has usually followed the conventional set of Social Movement Theories (SMTs) and, more recently, a post-Marxist approach. Despite their differences, these perspectives share key aspects: they conceal normative standpoints and take for granted concrete determinations of capitalists social relations. However, an alternative approach to analyse SMs, involving dialogue with those engaged in contemporary struggles and the adoption of a materialist ontology, has been gaining space. Within a Marxist perspective, it explores the inspiration that SMs can offer to our modes of theorizing, teaching and researching (COX, 2014). Sharing this assumption, in this paper we explore the implications of adopting an explicit materialist ontology to study SMs that oppose and confront the capitalist social order.

Taking into consideration that differences between theories or theoretical systems should be discussed at the ontological dimension, not merely at the epistemological, empirical or logic-formal ones, we address the differences between these perspectives through the ontology of social being formulated by György Lukács ${ }^{4}$ in his later work. For him, human practice is finalistic, it is the ideal positing of an end and its consequence is objectification. To use Lukács' (1978a, p. 43) term: it is teleological. Therefore, it presupposes the knowledge of real objects, relations, structures, etc., in a connection between subjectivity and objectivity subordinated to the priority of practice, which has a "guiding and controlling function for knowledge". Lukács' formulation on the ontology of social being (presented in the first section) provides support for the critique of the first two perspectives mentioned above (presented in the second and third sections, respectively). It also allows us to defend, in the fourth section, the relevance of the dual rhythm expressed in the movement from practice to theory and the movement from theory to practice, including facts that emerge from the ground, such as creativity in forms of struggle; and listening to the voices from below and to their theoretical/philosophical choices (DUNAYEVSKAYA, 1989).

\footnotetext{
${ }^{4}$ Lukács final work on ontology was written in the years 1964-1970. In the German and in its Brazilian translation, the book has been separated in two volumes, comprising around 1.500 pages. Just three chapters out of ten have been translated into English, each one in one book. The first focuses on Hegel, the second on Marx, and the third on labour. Besides this fragmentary presentation, the translations have various problems. Therefore, we will usually refer to the Brazilian editions of Lukács' ontology.
} 
Another source of inspiration for the reflection we make in this paper is our own research related to social movements and popular struggles, as well as in studies performed by colleagues and students of our research group. These researches have included, among others, anti-extractivist struggles; strikes, occupations and popular fronts in defence of public education and public transport; movements for the right of living and inhabiting.

All these processes offered inspiration for our reflections on key themes for the activists in their actions and debates. We also include a dialogue with propositions from intellectuals who engaged with SMs and/or oriented their work to oppose the system of capital. The aim is to provide an understanding that the political praxis is always, as Harvey (2000, p. 55) says, "embedded in ways of life and structures of feeling particular to places and communities". It is also an attempt to show how the primacy of practice relates to theory, while remembering that the former does not remove a certain limited autonomy from the latter (SÁNCHEZ VÁSQUEZ, 1977).

The aim of this paper is not to formalize an all-encompassing theory, which would repeat the reductionist perspectives that we criticize. Instead, we argue that the adoption of a materialist ontology to study social struggles indicates that we should take into consideration the practical/theoretical agenda embedded in each specific movement. It can contribute to how we approach a specific organizational phenomenon, thus re-establishing the mutual influence between Organization Studies (OS) Social Movements Studies (SMS) that, as we will show, marked the early developments of SMTs, but now in a very different direction.

Before starting the first part, let us explain the reasons why we have chosen the word 'struggle' instead of 'resistance'. This choice was inspired on the distinction made by Scott (1985, p. 32) between two styles of resistance: the first are "quiet piecemeal process" and "dramatic public confrontations"; the second are "everyday resistance" and "open defiance". In our reading, these differences indicate more than mere styles, they indicate different strategies: while the first refers to open social conflicts performed by collectives, and demands organization; the second indicates "low-profile forms of resistance that dare not speak in their own names" (SCOTT, 1990, p. 19) and, usually, are performed by individuals. These differences are clear and politically relevant and deserve to be named accordingly. Therefore, we have opted to refer to the first "style of resistance" as struggle, and to adopt the word resistance to refer to hidden and/or individual practices of defiance. 


\title{
1 LUKÁCS’ ONTOLOGY OF THE SOCIAL BEING
}

The ontological writings of György Lukács ${ }^{5}$ provide "a crucial way to find a concrete universal to which our theoretical and ethical categories can find reference [...] without any of the dangers of moral relativism" (THOMPSON, 2011, p. 230). Vaisman and Fortes (2014, p. 134-135) consider that this work makes "a clear statement on the ontological basis of Marx's reflections", while clashing "with the orthodox understanding of Marx that prevailed throughout the 20th Century" obscured by the dogmas that have plagued "almost all the currents of Marxism since the death of Lenin" and, at the same time, privileging "the question of the emancipation of man". It is the elaboration of an ontology of society based on Marx's “path-breaking originality”. Referring to Marx's writings, Lukács (1978a, p. 5) affirms that "for the first time in the history of philosophy the categories of economics appear as those of the production and reproduction of human life, and hence make it possible to depict the social existence ontologically on a materialist basis".

Lukács explains the meaning, in Marx's ouvre, of the priority of the economic (a very misunderstood argument, obfuscated by formulations related to the Second International ${ }^{6}$ ):

\begin{abstract}
If we ascribe one category ontological priority over the others, we simply mean that one of them can exist without the other, without the opposite being the case. This holds for the central thesis of all materialism, that being has ontological priority over consciousness. What this means ontologically is simply that there can be being without consciousness, while all consciousness must have something existent as its presupposition or basis. This does not
\end{abstract}

\footnotetext{
${ }^{5}$ Oldrini (2013) locates the ontological turn in the philosophical perspective of Lukács in the 1930', when he had access to the early writings of Marx and realizes the way Marx reconstructs ontologically the concept of 'objective being' that Hegel had lost in his speculative philosophy. However, the word 'ontology' did not come immediately, because of Lukács' refusal of Heidegger's connotation. It was only when he entered in contact with Ernst Bloch's (1986) "ontology of the not-yet-being" (noch-nich-seins), published for the first time in 1961, and with Nicolai Hartmann's (1975) "Ontology", that he assumed the possibility of developing a Marxist and materialist ontology.

${ }^{6}$ After Marx's and Engels' death, in 1883 and 1895 respectively, historical materialism has gone through distinct and conflictive paths, starting by the conceptions of economic determinism and evolutionary socialism as in Eduard Bernstein and Karl Kautsky. These were the intellectuals who most influenced the Second International, an organization of socialist and labour parties which had its first meeting in 1889. For Oldrini (1999), the lack of an elaborated philosophical system in Marx and Engels writings created a situation in which their followers became dislocated and vulnerable, with no doctrinal system to oppose their adversaries. Instead of developing Marxism in Marx's dialectics direction, they fell into "an incoherent eclecticism, according to which it was necessary to complete, from the outside, Marx's economic doctrines". In the philosophical dimension, Second International Marxism incurred in economistic limitations; it became a unilineal doctrine, in which "economy determine rigidly all of the other dimensions of reality". In the political dimension, it resulted in a fatalist perception of capitalism and a natural evolution towards socialism. "From the Marxian law of the inevitable growing of capitalism contradictions, it is immediately deduced the consequence that, when contradictions are mature and explode, capitalism defeat occur by itself' (OLDRINI, 1999, p. 69).
} 
involve any kind of value hierarchy between being and consciousness. (LUKÁCS, 1978a, p. 31)

The ontological priority of being over consciousness goes pari passu with the priority of the economic over any other social complex: language, the law, the political, the ideological, etc. This does not mean that the former precedes or determines the latter in a mechanistic way; it means that without the former (economic relations of production and reproduction of life), the latter cannot even exist.

We have already mentioned that human practice is teleological. Labour is central in this formulation because the creation of use-values is a condition of human existence that is independent of all forms of society, for the simple fact that no human activity would be possible if human beings could not reproduce their own life. Labour is also central because, through it, "a teleological positing is realized within the material being, as the rise of a new objectivity" (LUKÁCS, 1978b, p. 3). Labour, then, is the starting point to understand the social being in ontological terms, because all other categories (language, cooperation, division of labour, consciousness, etc.) presuppose a social character. Labour - "the original phenomenon", "the model for all social practice", the exclusively human activity that makes "teleological positing" real - can be used to illuminate other kinds of social positing (LUKÁCS, 1978b, p. 46) because the teleology entailed in labour is what distinguishes this specific human practice from the reproduction of other forms of being (organic and inorganic).

Teleological positing, understood as an intentional activity, expresses and operates under a set of propositions about the causal properties of things in the world, i.e. knowledge. In other words: "[...] any practice, even the most direct and everyday, can be seen to have this connection in relation to understanding, consciousness, etc., because it is always a teleological act, in which the projection of goals precedes their realisation, both actually and chronologically" (LUKÁCS, 1978a, p. 43). However, in the course of human development, the knowledge acquired through practice has followed two distinct interconnected paths: on the one hand, when correctly generalized, knowledge that emerges from immediate practice is integrated into the human conception of the world; on the other, this knowledge remains confined to direct usability in immediate practice (DUAYER; MEDEIROS, 2005).

Lukács (2012, p. 58) criticizes neopositivism for its "proclamation of the superiority of the principle of manipulation over any attempt to understand reality as reality". It is the 
transformation of the second trend mentioned above (knowledge that remains confined to direct usability in immediate practice) into a general doctrine of science, making the "entire system of knowledge" an "instrument of the general manipulability of all relevant facts" that naturalizes the existing order and, at the same time, denies any possibility of transcending it while refusing substantive notions about the world and the relations that bring it to exist such as it is.

This very brief introduction to Lukács' ontology helps us to present the notion of ontological critique: a criticism that not only demonstrates the falseness or incompleteness of a determined belief, dissolving its apparent naturalness, but also acknowledges its function in the social practice.

It also allows us to present the specificities of political praxis as a teleological positing that aims to modify the existing social order. Before developing this idea, we should clarify the meaning of praxis. What differentiates it from mere activity and defines it as a properly human activity is that the actions taken to transform an object start with the ideal result or end and conclude with the real result. There is, hence, the interference of consciousness. If praxis is human activity and the means for the creation of a new reality, it is possible to speak of different levels of praxis in accordance with the presence of the active subject's consciousness regarding the transformative process. Based on this argument, Sánchez Vásquez (1977) distinguishes between creative and bureaucratized praxis. The former is unpredictable and demands elevated consciousness, the latter only covers pre-existing forms with new clothes, the content is sacrificed to the form, the real to the ideal, the concrete particular to the abstract universal. Lefebvre (2014) makes a similar distinction: repetitive and creative praxis.

We can now address the specificity of political praxis: it always has an ideological substance. Lukács (2013, p. 465) defines ideology as a form of "ideal elaboration of reality that makes human praxis conscious and capable of acting". Its "immediate origin is in the social here and now (hic et nunc) of the human beings who act socially and in society": "ideology is the means for the social struggle" (LUKÁCS, 2013, p. 465). Therefore, it is only possible to apprehend an ideology and its content by considering its social function in concrete antagonistic circumstances, not from the analysis of its gnoseological character of true or false consciousness.

Lukács (2013, p. 506) offers two criteria for analysing political praxis as teleology: effectiveness and duration. The first corresponds to the immediate dimension of politico- 
ideological practice, "a real conflict caused by factors that are, in the final analysis, economic, and can be confronted and overcome by political means"; the second is an effect of the political activities that "set in motion the processual nexus of the fabric of society leading to a chain of consequences that serve to maintain society in its current form" or, alternatively, that "act by transforming the sociability and giving a new course of direction" (VAISMAN; FORTES, 2014, p. 140).

Inspired by Lukács' propositions, our aim in the following section is to engage critically with SMTs, considering their connections with the field of OS.

\section{THE DOMINANT APPROACH IN THE STUDY OF SOCIAL MOVEMENTS: A CRITIQUE}

According to Cox and Fominaya (2013, p. 7-8), "anyone researching SMs will find themselves hearing or reading a near-identical account, often repeated word-for-word, of how the discipline came to be". They continue: "it is a tale of the bad old days of collective behaviour theory, followed by the rise of resource mobilization theory, the addition of political opportunity structure, the encounter with ('European') 'new social movement' theory (NSMT) and the arrival of framing theory". This 'origin myth', as the authors name this account, represents the "uncritical translation of US exceptionalism (the historical weakness of the political left and labour movements)". The authors provide, then, an alternative narrative introducing references from the European SMs practices and theories, concluding that "perhaps it is time to break free of the idea that it is necessary to use SMTs, as currently defined, to study movements" (COX; FOMINAYA, 2013, p. 25).

A critical account of the origins of SMTs also demonstrates it has been strongly influenced by approaches constructed to analyse business organizations; and that theories identified with North American SMTs orthodoxies share common ground with Organization Studies (OS) orthodoxies. According to McAdam and Scott (2005), in the mid-1960s, a group of young scholars (including GAMSON, 1968; TILLY and RULE, 1965; ZALD and ASH, 1966) began to formulate arguments to account for social unrest, converting the earlier focus on collective behaviour to one on collective action, SMs, and social movement organizations (SMOs). Most of this work employed an institutional perspective and reframed the view of protests and demands for reform from one of reactive individual behaviour (SMELSER, 
1962) to one involving instrumental action, mainly focusing on the political process and two mechanisms: resource mobilization (McCARTHY and ZALD, 1977) and political opportunities (TILLY, 1978). In the 1980s, the NSMT emerged in the European context to analyse movements that, in a society defined as post-industrial, organized around issues such as ethnicity, sexuality, environmentalism, pacifism and human rights. The main concerns were related to identity, culture, and meaning (TOURAINE, 1985; MELLUCI, 1989).

The decades that followed witnessed theoretical developments that attempted to approximate these two branches, such as the influential work of Tarrow (1998). For him, SMs emerge and spread in response to political opportunities and, in the sequence of events, create new opportunities and possibilities for the conformation of new identities (MCADAM; TARROW; TILLY, 2001). Complementing that work, McAdam, McCarthy and Zald (1996) introduced the cognitive mechanisms-based approach, known as the "framing process", to analyse the importance of socially constructed and shared ideas (ZALD, 1996). It is also important to mention the very influential structuralist model of analysis disseminates by Tilly (2008) in which SMs are defined by the combination of three elements: campaign; repertoire; and the display of worthiness, unity, numbers and commitment. In these approaches, it is easy to recognize the importance given to environmental factors and institutions to the organization and success of SMs.

Perhaps the best-known critique of SMTs is related to its 'structural bias', i.e., the adaptation of SMs to structural constraints given by its social, economic or institutional environment, operationalized by the analyst using the main categories: political opportunities, mobilization of resources, and framing. Critical theoretical and epistemological discussions on these models usually emphasize the imposition of structure over agency and the impossibility of the conceptual models to address different dimensions in the objects under scrutiny. The main problem is the practice of constructing a theoretical model, which is used to analyse what is taken as a passive, obscured and undertheorized object. The same happens to the distinct social process in which it emerges.

According to Duayer (2015), this scientific practice is characterized by a tautological movement in which the researcher comprehends social processes through his own system of beliefs, ideological coordinates and ontological schema, looking for regularities and behaviour patterns that fit his own presuppositions. The result "can only consist of empirical regularities between phenomena or stable functional relations between observable variables 
from the perspective given by theories" (DUAYER, 2015, p. 101). The implicit ontological presupposition is that the world consists of atomized phenomena that can be interpreted following a set of theoretical axioms.

SMT also has an ideological character that can be easily identified if we consider the strong influence of OS, mainly in the North American context. One example is the development of the theory of resource mobilization born out of OS in dialogue with Olson's (1965) rational choice approach. For Diani (2000, p. 5), this is an interesting case of how an analytical perspective (OS), when creatively applied to a new empirical domain (SMs) to highlight some specific processes, "becomes increasingly popular among practitioners whose main intellectual identification is with the specific empirical field rather than with the approach, and eventually is turned into a theory of the empirical object".

In a similar fashion, Misoczky, Flores and Silva (2008, p. 12) argue that a "theory abstracted from capitalist organizations within the North-American context in last century is being used to explain contemporary social movements, many of them anti-capitalist and in different contexts". The authors go even further, showing the process of appropriation of SMTs by business-oriented scholars, using SMs practices to propose models and instruments of management, homogenizing SMs and business enterprises under the label of 'organizations' (CLEMENS, 2005). This mutual influence explains the fact that a search in two of the main international journals in the field of OS - Organization and Organization Studies - using the term 'social movements' showed that the study of SMs not only takes business-oriented literature as the main references (see DUBUISSON-QUELLIER, 2013; HENSBY, SIBTHORPE and DRIVER, 2011), but also tends to analyse them by reproducing the logic applied to business organizations (see YAZIJI and DOH, 2013).

The implications of this include the adoption of the reified definition of organization (present, for example, in the term Social Movement Organizations), which constitutes an obstacle to accepting the study of the organizational practices of movements as genuinely belonging to the field of OS; the adoption of analytical criteria such as success, performance, and influence; an emphasis on structural and environmental aspects; and a tendency to value the reproduction or creation of new orders. Another finding was an overwhelming predominance of articles based on institutional perspectives ${ }^{7}$.

\footnotetext{
${ }^{7}$ Some examples are presented here. Bertels, Hoffman and DeJordy (2014) explore the nature of the work undertaken by institutional challengers in the US environmental movement, drawing on the tools of social network analysis. Haug (2013), building on the concept of partial organization, develops the concept of meeting
} 
In addition, in agreement with Goodwin and Jasper (1999, p. 34), we may recognize the capitalist liberal social ideology as the background for the dominant approaches - much of the theorization was produced when analysing "movements pursuing political participation or rights, notably the labour and civil rights movements" in the USA. In turn, the NSMT approach originated mainly in Europe in the 1970s and 1980s with the rise of movements that brought to the political agenda issues such as ethnicity, ecology, gender, etc. A consequence is that the values and world vision behind these theoretical models prevent fruitful dialogues with movements that struggle to transcend social established orders and values.

This leads us back to Lukács (2012, p. 58) and to his proposition that "the refusal of every ontology means, simultaneously, the proclamation of the superiority, as a principle, of manipulation over every attempt to comprehend reality as reality". He argues that positivism achieved a "maximum conceptual perfection" that led to neopositivism, in which a specific "theory of knowledge becomes a regulatory technique of language, of transformation of semantic and mathematical signs, of translation of one language into another". Taking these reflections into consideration, we argue that practical relevance cannot be a definitive criterion to judge the value of a body of knowledge or a theory.

We introduce this discussion because of the popularity of Bevington and Dixon's (2005) argument about SMTs' irrelevance from the activists' standpoint. They correctly describe a situation in which activists and those who were supposed to benefit from SMTs do not read and do not use it. "The reason for this", they contend, "is that activists do not find such theory useful" (BEVINGTON; DIXON, 2005, p. 186). They then draw on Flacks (2004) to argue for the need of a movement-relevant theory, i.e., a theory that seeks "to draw out useful information from a variety of contexts and translate it into a form that is more readily applicable by movements to new situations - i.e. theory" (BEVINGTON; DIXON, 2005, p. 189). Their concept of usefulness, as already mentioned, was borrowed from Flacks (2004), who proposes that studies should provide clues about how to accomplish frame alignment, the

arena - a hybrid of three forms of social orders (organization, institution and network). Bakker, Den Hond, King and Weber (2013, p. 573), introducing a special issue on SMs, civil society and corporations, suggest three research areas: "the blurring of the three empirical domains and corresponding opportunities for theoretical integration, the institutional and cultural embeddedness of strategic interaction between agents, and the consequences of contestation and collaboration". Özen and Özen (2009, p. 547) consider that the integration of "neo-institutional and SMT for a better understanding of social institutional change offers a partial picture concerning the roles of the state and society in institutional wars". Finally, Soule (2012), reviewing the nexus of organizational and SMT, and reflecting on the Occupy movement, suggests five lines for future researches: police response to threat as an organizational issue; the extent to which public protests may inspire less overt forms of action - what we would refer as resistance; the role of religion in anti-corporate protest; how organizational learning theories can help to understand diffusion and the dynamics of coalition formation. 
value of informal networks and the importance of opportunity structures. In other words, a useful theory would show activists how to operationalize these concepts and categories. This is confirmed by the authors' adoption of Perrow's (1970, p. viii) statement in the Foreword of his classical Organization Analysis, as an epigraph: "One test of good theory is that it has practical implications. [...] What a theory does is to show how to analyze an organization or an organizational problem, in a way to enable a rigorous selection of specific techniques".

This is precisely Lukács' (2012, p. 58) critique of knowledge as "an instrument of general manipulability", because it naturalizes the social order, thus enabling, for example, SMs to identify political opportunities in the structure and fit into them while, at the same time, denying the possibility of transcendence. Instead, it is necessary to produce a knowledge that explains the material fundaments of the existing order as a mediation to intervene and transform it. In other words: praxis. Relevance is not a matter of generalization and applicability, it relates to the necessary comprehension of the processual fabric of society in its relationship with the actual political action (LUKÁCS, 2013).

This problem is in tandem with Goodwin's $(2012$, p. 10) reference to "the strange disappearance of capitalism" in SMS, which "lacks not only any anti-capitalist spirit but usually any explicit normative standpoint; they seem more concerned with contributing to the specialized academic literature on movement dynamics than with pondering how movements might lead us to the good society" (GOODWIN, 2012, p. 8).

The reasons for that are various and very much discussed in OS and social sciences in general. They are related to the emergence of post-modern and post-structuralist approaches a phenomenon that reflects, in knowledge production, the emergence of neoliberalism and the end of the Socialist bloc. One consequence has been that SMS "largely abandon the path of tracing movement development back to the conflicts generated within the lifeworld by power, exploitation and ideology" (COX and NILSEN, 2007, p. 429). This consideration leads us to critically engage with Laclau and Mouffe's post-Marxism in the following section.

\section{SOCIAL MOVEMENTS AS CHAINS OF EQUIVALENCE: A CRITIQUE}

Alone, and together with Chantal Mouffe, Ernesto Laclau has written many books and papers on political theory and social sciences. We decided to include the discussion of Laclau and Mouffe's (2001) seminal book Hegemony and Socialist Strategy because the theoretical 
propositions it contains have been widely applied in the analysis of SMs and organizations in general and particularly in $\mathrm{OS}^{8}$. In the next paragraphs, we briefly present Laclau and Mouffe's arguments.

Laclau and Mouffe's central concern is operational; not ontological. In proposing a theoretical framework and a new strategy for the left, they clearly state in the Preface to the second edition of Hegemony that "the problem with 'actually existing' liberal democracies is not with their constitutive values crystallized in the principles of liberty and equality for all, but with the system of power which redefines and limits the operation of those values" (LACLAU; MOUFFE, 2001, p. xv). Published sixteen years after the first edition, the Preface incorporated the label 'post-Marxist', which the authors did not create, but accepted.

The book's main argument, in strategic and practical terms, is that "struggles against sexism, racism, sexual discrimination, and in defence of the environment need to be articulated with those of the workers in a new left-wing hegemonic project" (LACLAU; MOUFFE, 2001, p. vviii). The starting point is a critique of the reduction of any strategic and analytical perspective to class relations or class struggles, which is defined by them as class essentialism. This argument is based on an anti-dialectic reading of Marx that followed the trends inaugurated mainly by Kautsky (defined by Trotsky (1919) as the propagandist and vulgarizer of Marxism) and legitimized by the Second International. In Laclau and Mouffe's writings, Marxism can be understood as being synonymous of a deterministic relation between base and superstructure (see footnote number 3 ).

Laclau and Mouffe (2001, p. 69) centrally engage with the concept of hegemony, but in a radically reformulated version of Gramsci's (2006) concept. They sever the material connection of both the hegemonic and subaltern groups to the social structures and instead privilege contingency and articulation. For them, the main condition for hegemony is that

\footnotetext{
${ }^{8}$ Some examples of studies using Laclau and Mouffe's schema to analyze social movements are presented below in a non-exhaustive list. Spicer and Böhm (2007, p. 1667), asking how to understand "multiple forms of resistance against the discourse of management", addressed four resistance movements - unions, organizational misbehavior, civic movements and civic movement organizations, and discussed possible interconnections between those different forms of resistance. Contu, Palpacuer and Balas (2013, p. 381) identified a collective resistance of workers against the restructuring of two industrial plants in France. They focused on the alignments and alliances, and argued that "subject mobilization also comprises specific articulations that are important in establishing the resulting identities and interests at stake". In another paper, Van Bommel and Spicer (2011, p. 1717) analyzed the slow food movement through Laclau and Mouffe's schema and the concept of 'institutional field', arguing that slow food "forged hegemonic links among a range of disparate actors". Otto and Böhm (2006, p. 312), in turn, analyzed the Coordinadora Departamental en Defensa del Agua y de la Vida struggle for water in Cochabamba, Bolivia, and concluded that "the articulation of a variety of different demands was channeled into a common demand: water."
} 
"elements whose own nature does not predetermine them to enter into one type of arrangement rather than another, nevertheless coalesce, as a result of external or articulating practices" (LACLAU; MOUFFE, 2001, p. xii). To achieve hegemony is to articulate diverse discursive elements in opposition to an antagonist one. Therefore, there are no privileged ontological agents of struggle (CONTU, 2002); instead, social agents coalesce in a contingent manner through chains of equivalence.

In fact, Gramsci (2006) widened Marx's class perspective in such a way that the subaltern and the dominant remain the two main groups in any social struggle, but they are not only an expression of the division of labour between capitalists and workers, they are also involved in the intellectual struggle: a struggle over concepts, world views, ideologies and projects. This seminal contribution is criticized by Laclau and Mouffe (2001, p. 69). In their reading, "[...] a failure in the hegemony of the working class can only be followed by a reconstitution of bourgeois hegemony, so that in the end, political struggle is still a zero-sum game among classes. This is the inner essentialist core which continues to be present in Gramsci's though, setting a limit to the deconstructive logic of hegemony".

For Laclau and Mouffe, the main condition for hegemony would be a dialectics between logics of difference and logics of equivalence. Let the authors explain the schema:

\begin{abstract}
Social actors occupy differential positions within the discourses that constitute the social fabric. In that sense, they are all, strictly speaking, particularities. On the other hand, there are social antagonisms creating internal frontiers within society. Vis-à-vis oppressive forces, for instance, a set of particularities establish relations of equivalence between themselves. It becomes necessary, however, to represent the totality of the chain, beyond the mere differential particularisms of the equivalential links. What are the means of representation? As we argue, only one particularity whose body is split, for without ceasing to be its own particularity, it transforms its body in the representation of a universality transcending it (that of the equivalential chain). This relation, by which a certain particularity assumes the representation of a universality entirely incommensurable with it, is what we call a hegemonic relation. (LACLAU; MOUFFE, 2001, p. xiii)
\end{abstract}

Although very influential, this approach has also been heavily criticized. For the sake of space, we mention just two of these appraisals. For Dussel (2001, p. 200), it is not possible to find the "criteria which enable political and strategic action to exert hegemony which is not for mere hegemony, but in favour of the oppressed". For Martín (2014, p. 122), "class struggle has a subjective and contingent moment; but this is not autonomous in respect to the blind and objective logic of capital where it occurs". More than that: "the hypostasis of ontological contingency in any factual situation [...] impedes the understanding of the forms 
of domination historically determined in capitalism (tied to objective and reified dynamics of value)" (MARTÍN, 2014, p. 124).

In contrast to the ontological priority of the economic, which according to Lukács (2012) defines a materialist ontology; Laclau and Mouffe's (2001) approach is based on the priority of discourse and contingency. They do not provide analytical tools to comprehend the structural determinants of the real. Therefore, this approach is not capable of making a dialectical movement, instead, it starts in the superstructure and there it remains. The world that lies behind it is a relatively harmonious one in which, as liberal democratic theory defends, everyone would be able to articulate against anything; a process that conceals concrete differences and impedes any attempt at radical transcendence. In other words, it allows what Bonefeld (2012, p. 124) defines as a "reified consciousness", in which it is enough to "declare that the enemy of my enemy is my friend" indifferent to the "ends and social contents that hold sway in things" (BONEFELD, 2012, p. 129).

This implies a relativist position in which the emphasis on contingent articulations and antagonisms ensures the core contradiction from which social conflicts originate apparently disappear, together with the connections between social groups and movements and the material base of their existence. It opens the possibility of assuming a world without necessities, something Chasin (2000, p. 17) has called politicism: the naturalization of the economic and the overvaluation of the political. In such an approach, "the economy is considered a kind of amorphous wallpaper, a virtual platform full of possibilities to be defined by the political - a correlation of forces that constitute alliances".

By obscuring structural elements, class positions, and social necessities, this approach induces interpretations regarding social conflicts in which the activists, social struggles, organizational practices and distinct processes cannot be linked to any position in concrete material realities. This perspective interdicts attempts to address the multiple determinations of the real, let alone propose and inform any attempt to radically transform the world. It expresses an ontology in which social being has no essence, no history, in sum, is floating in a void, to use Bashkar's words in a debate with Laclau (LACLAU; BASHKAR, 1998); an implicit antirealist premise, which places the truth in the propositions (discourses) about things, instead of placing it in the things themselves (NORRIS, 1996).

The refusal to differentiate essence from appearance poses a serious risk for knowledge production, because it avoids questions about the causal relations that bring reality 
into existence. Therefore, human beings are not capable of "grasping the precise nature of a complex phenomenon in relation to the general laws that condition it and from which it simultaneously appears to deviate" (LUKÁCS, 1978a, p. 106). Instead, they would only be capable of a bureaucratic, repetitive praxis, which remains prisoner of the contingent immediacy and incapable of transforming the oppressive reality.

When used to study SMs, Laclau and Mouffe's propositions lead scholars to reach generic and insufficient findings, which tend to emphasize operational aspects. This has an obvious consequence from the perspective of knowledge construction but may have an even more adverse effect if it induces strategies that neglect the material content and circumstances of social conflicts.

Having presented our critiques in the sections above, we can now introduce our theoretical and methodological positions.

\section{THE DIALECTICAL MOVEMENT BETWEEN PRACTICE AND THEORY}

Barker, Cox, Krinsky and Weber (2013, p. 1-2) make the case for a Marxist revival, discussing "how the concept of 'movement' might be interwoven with other foundational concepts in Marxist theory", such as class struggle, hegemony, revolution, generic-being, alienation and praxis. They also recognize that mainstream SMT "consistently avoids debate with Marxist perspectives, although they constitute by some margin the largest alternative body of research on popular movements". Similarly, Nilsen and Cox (2013, p. 64) discuss what a Marxist SMT would look like. According to them, it would have to be geared towards "the open-ended analysis of movement-processes in specific places", it would need to encompass everyday struggles "to make sense of the way in which activists can move from one towards the other through collective learning".

Engaging with these arguments and replacing predefined research agendas and/or prescriptive theories external to the activist's experience and everyday organization (COX, 2014), we value the inspiration SMs can offer. Avoiding the institutional-political reductionism, which led SMTs to "largely abandon the path of tracing movement development back to the conflicts generated within the lifeworld by power, exploitation and ideology" (COX; NILSEN, 2007, p. 429), as well as the relativism of post-Marxism, we follow the inspiration provided by Dunayevskaya's (1982) reflections based on her own 
activism during the so-called freedom movement that marked the intermediate decades of the last century in USA. She realized that blacks, women, workers and youth were not faceless masses to be led, but rather the producers, by their very actions, of a theory of human liberation that emanates from the dialectical movement from practice to theory and from theory to practice.

An illustration comes from the uniqueness of the Women's Liberation Movement (WLM) in challenging not only chauvinism under capitalism, but the left-wing movement itself. The long previous history of women that confronted exploitative working conditions and demanded rights (such as the right to vote), both in the North and in the Global South, finally became a movement expressing ideas whose time had come. In the 1960s, women speaking in many voices and in many places worked out their own vision (DUNAYEVSKAYA, 1989) and produced a body of knowledge that keeps informing many struggles since then. A wide set of heterogeneous theories could not come to exist without praxis, without the concrete struggles and the constant reflection, without the indispensable knowledge of the many forms of oppression that made the organization to confront them necessary and possible.

This historical movement, which has been able to articulate a universal value (women's liberation) out of situated struggle, is an illustration, not a model. Our argument is, in agreement with Cox $(2017$, p. 6), that "there is no safe place to stand within language or theory". It is "in the real human practice that the actual meaning of particular words, organizations, and traditions in particular places become clear".

This statement reflects a "critical realist ontology", which combines "the recognition of underlying realities with a critical approach - one that reaffirms the necessity of how things currently are, but acknowledges its constructed character and hence the possibility of challenging and changing structures" (COX; NILSEN, 2014, p. 17). In that same vein, Lukács' ontology provides a complex set of propositions, which, for reasons of space, we are unable to fully explore in this paper. Therefore, our aim is to take his main ideas and categories and use them to think about how we can gain a clearer understanding of "the people who move and the things they move against", in the words of Cox $(2017$, p. 3). Therefore, our work has connections with that of Cox and colleagues, and our specific contribution is to draw on an explicit materialist ontology, which is, so far, quite implicit in its developments. 
We also include ourselves among the activists and/or academics who defend the need to articulate two dimensions of critical reflexive thought: theoretically elaborated knowledge; and knowledge that emerges from below and remains, most of the time, restrained to the praxis and spaces of struggle (RAUBER, 2004). Malo (2004) also defends the possibility of producing knowledge through research processes that articulate theory and praxis, that take the concrete reality as the starting point, that move from the simple to the complex, from the concrete to the abstract, that share the aim of creating a theoretical content that is relevant and meaningful because it is attached to the everyday life of activists and to the organizing processes.

It should be clear, by now, that we understand knowledge as "the interaction between differently-situated, experientially-grounded and practice-oriented modes of knowing", not arriving only from closed spaces or "from participation in an invited place, but rather through claimed or created spaces intended to enable discussion between different modes of knowing" (COX, 2014, p. 961). Accordingly, theory is a tool used to figure out what is happening, why it is happening and what to do about it, "by going beyond the immediaticy and situatedness of a particular experience" (COX; NILSEN, 2014, p. 21).

The engagement with the practical, sometimes tacit, knowledge that is articulated in the concrete movement demands a close relationship with activists and their organizational practices. There is a long tradition of qualitative research methods that respect the ethical and political purposes of movements. This is the case, for example, of participatory action research, a confluence of critical theory and social pedagogy (mainly popular education and the critical pedagogy of Paulo Freire, 2005), which aims to articulate research and practical interventions with knowledge, experience and the needs of local communities. As Fals Borda (2012, p. 213) puts it: "how to research reality to transform it through praxis". Another key element is the process of co-research in which the participants are partners sharing values (KINCHELOE, MCLAREN and STEINBERG, 2011).

Another example is militant workers' self-inquiry, which originated in Marx's questionnaire to be circulated among the French working class in 1880, renewed by dissident Italian Marxism in the 1960s and 1970s (PANZIERI, 1994). The workers' inquiry is a kind of co-research - a form of research that tears down the division between the subject-researcher and object-researched (MALO, 2004). More recently, such approaches have been extended to militant research - the place where academia and activism meet in the search for new ways of 
acting that lead to new ways of thinking (BOOKCHIN, BROWN, EBRAHIMIAN et al., 2013).

These approaches express an attitude that requires a willingness to think, to listen, to see, to feel, to taste the world from the perspective of the Other; it is conditioned by humbleness and solidarity, following Dussel's (1974) 'analectics'. Alcoff (2011, p. 67) defines analectics as "an epistemology for the new revolution", because it puts "at the center not simply the objective conditions of global impoverishment and oppression, but the systematic disauthorization of the interpretive perspective of the oppressed".

In the next section, we present some topics that form the theoretical agenda that emerged from the struggles we have been engaging with and from an analysis that seeks to advance a way of thinking, theorizing and transforming concrete reality in a dialectical movement from practice to theory and from theory to practice. The topics are: spontaneity/organization, autonomy/organization, horizontality, and the occupation of public spaces.

\section{TOPICS FOR AN AGENDA OF RESEARCH IN DIALOGUE WITH POPULAR SOCIAL MOVEMENTS}

\subsection{SPONTANEITY/ORGANIZATION}

Debord (1965, p. 3), writing about the Watts Riots, asked: "How do people make history under conditions designed to dissuade them from intervening in it?". This critical question has been posed by many in relation to social upheavals that have taken almost everyone by surprise, upsetting structures and bringing new elements of social life that "become briefly visible in luminous transparency" (LEFEBVRE, 1969, p. 7). Some have looked for answers in the idea of a spontaneous coming together; others insist on the previous existence of ceaseless practices of grassroots organization.

For Roesch (2012), as well as Fernández, Sevilla and Urbán (2012), spontaneity and organization exist in a constant dialectical relationship with one another. For these authors, there is no such thing as pure spontaneity: at some point, the accumulated indignation breaks to the surface, but it incorporates previous histories of resistance and seemingly fruitless struggles, small demonstrations of a few hundred people, years of patient organizing work, 
small victories and big defeats, dreams and frustrations. The ceaseless organizing of many activities can only assume forms that are more definite when the struggle emerges on a higher level. Nonetheless, the organizing done in periods of calm is not only critical but also shapes the character of the mass struggle that emerges: "Out of a whole series of small battles, elements of leadership begin to form, different politics begin to emerge, and certain tactics, symbols, and themes begin to develop and resonate. Connections are formed, are sometimes lost, but then re-emerge as struggle begins to develop at a sharper level" (ROESCH, 2012, p. $5)$.

For Lefebvre (1969, p. 69), writing immediately after the events of the French May 1968, "there is, of course, no absolute spontaneity. [...] The explosion of spontaneity arises out of prior conditions". The author offers further elaborations on the meaning of spontaneity: (a) it is triggered when lags accumulate, involving the range of distortions and disparities; (b) it is in the streets that spontaneity expresses itself, because this is an area of society not occupied by institutions; (c) spontaneity and the transformation of the streets into political arenas leads to the phenomenon and problem of violence; (d) deep-seated spontaneity is not only a reaction to disparities and accumulated lags, but are also a symptom of new contradictions. "Drawn in by the void, spontaneity begins to fill it." However, "spontaneity needs an orientation. It requires a kind of thought which can understand it, which can guide it without shifting it" (LEFEBVRE, 1969, p. 51).

Luxemburg's (2004) theory of mass action (inspired by the 1905 Russian Revolution) is still helpful when considering the role of political leadership in expressing the significance of mass actions and to clarify their goals. For her, mass actions produce the conditions for the organizational work to begin, in a movement from spontaneity to conscious political organization. Writing about the struggle in Russia, she said: "[...] the apparently "chaotic strikes and the 'disorganized' revolutionary action after the January general strike are becoming the starting point of a feverish work of organization" (LUXEMBURG, 2004, p. 186). It is a mistake to portray Rosa Luxemburg as an advocate of spontaneity against organization. In fact, she opposed the substitution of the working-class self-organization by bureaucratized vanguards but reflected on the dialectics between spontaneity and organization. It is in the spontaneous movement that the disorganized, the unconscious, the naïve, can become conscious of the class situation and organize collectively to become a political subject. 


\subsection{AUTONOMY/ORGANIZATION.}

According to Bonefeld (2004, p. 5), the aim of autonomy is human emancipation and human emancipation can only be achieved by the self-organization of the exploited regardless of pre-existing forms, like the party or the union. He refers to "the autonomy of social selfdetermination against forms of organization that derive their rational from capitalist society and are thus interested only in their own continued existence". Against conceptions of autonomy associated with Hardt and Negri's (2000) notion of human molecules and forms of bio-power, Bonefeld (2004, p. 3) argues that "autonomy without organization is a contradiction in terms". Autonomy, "if it takes itself seriously, requires organizational forms of negativity" because there are no free autonomous spaces within capitalism. Therefore, selforganized negation, in the form of social autonomy, expresses the struggle against capital and its state, and associated institutions of social integration.

However, it is important to be cautions and to avoid the exclusive focus on small utopias. The emphasis on local solidarities and autonomous organization run the risk of condemning as eminently bureaucratic and authoritarian traditional instruments of popular struggle, such as unions and parties, which are judged in terms their organizational forms instead of the content of their action.

\subsection{DIALOGICAL HORIZONTAL ORGANIZATION}

Sitrin (2005), writing in the Argentinean context in which the term horizontality emerged (from the organization of grassroots autonomous movements), defined it as a mode of political organizing characterized by non-hierarchical relations, decentralized coordination, direct democracy, and the striving for consensus. In the field of OS, Maeckelbergh (2014, p. 350) provided a softer definition, accepting some hierarchy. For her, horizontality is "a term used by movement actors to refer to less hierarchical, networked relationships of decisionmaking and the creation of organizing structures that actively attempt to limit power inequalities". In a nuanced definition, including delegation and the existence of a kind of leadership, Misoczky and Moraes (2011) defined horizontal organizational practices as having the following characteristics: lead by obeying (mandar obedeciendo - a principle that 
originated in the Mexican Zapatista movement); direct participation; collective deliberation; authorized delegation; co-responsibility.

In another work, Moraes and Misoczky (2010) used an approach based on Freire's theory of antidialogical and dialogical action to analyse the organizational practices of a piquetero organization in Argentina. This appropriation can contribute towards the development of further insights into horizontality. Freire (2005) often addressed the need for the conscious self-organization of the oppressed as a means for achieving their liberation. In his theory of oppressive action, he discussed the characteristics of antidialogical action: (1) conquest - necessity for conquering the other in order to impose objectives; (2) divide and rule - the oppressor minority must divide the majority in order to remain in power and halt, by any means (including violence), any action that could awaken the oppressed to the need for unity, organization, and struggle; (3) manipulation - the dominant try to conform the masses to their objectives; (4) cultural invasion - the cultural context of another group is disrespected by the imposition of world views, inhibiting the creativity of the invaded by curbing their expression. In contraposition, Freire (2005) developed a theory of dialogical action, which also has four characteristics: (1) cooperation - social subjects meet in order to transform the world; (2) unity for liberation - the leaders must dedicate themselves to an untiring effort to achieve unity among the oppressed and unity of the leaders with the oppressed; (3) organization - it is not only directly linked to unity, but is a natural development of that unity, it is also the antagonist opposite of manipulation; (4) cultural synthesis - cultural action, like historical action, is an instrument for overcoming the dominant alienated and alienating culture.

\subsection{ORGANIZING UTOPIAN SPACES: THE POWER OF THE STREETS}

Lefebvre (2003) identified three types of space: (1) isotopies - identical spaces that can be compared, quantified and mapped, spaces of order and rationality; (2) heterotopies ambiguous spaces, both excluded and interwoven; and (3) utopies - non-places, spaces of consciousness, imagined spaces that contain the promise of liberation and transcendence. When the movement of May 1968 took the Quartier Latin, in Paris, Lefebvre (1969, p. 118) wrote: "[...] the utopian locality came to assume an extraordinary presence". The power of 
the streets has the force to shake up societies, or at least to produce or reveal an institutional crisis. It is an effective power, even if transitory. However,

\begin{abstract}
When the process of dis-alienation through unfettered speech, street activities and spontaneous disorder - when this dis-alienation process ebbed, the order of everyday existence reorganized itself in its down-to-earth solidity. This disruption of the social order came to be viewed as disruption of everyday existence; the restoration of everyday existence supports the restoration of social order (LEFEBVRE, 1969, p. 89).
\end{abstract}

Strategies of constructing spaces of popular power, which include marches and open public assemblies in parks and squares, mainly in the city centre but also in peripheral neighbourhoods, are examples public interventions that produce transient utopic spaces. At the heart of the real, they explore the realm of possibilities.

However, to transform possibilities into reality it is important to avoid "falling in love with the beautiful moment" of the masses in the streets and take into consideration the risks of fragmentation, political impotence and/or the expression of traditional and new expressions of conservatism (ROMANDO and DÍAZ PARRA, 2019, p. 22).

\title{
FINAL REMARKS
}

Organization, for Lukács (1971, p. 299) "is the mediation between theory and practice", it is praxis. This means, that which is theoretical, an idea, must be made present organizationally to become practical in a real struggle. It is the teleological positing that reproduces, in the political praxis, the original phenomenon of labour, the exclusive human activity that operates under the knowledge of the causal properties of things in the world (LUKÁCS, 2012). Things that can be transcended by knowing and acting, by praxis.

The distinct contribution of this materialist ontology to the study of SMs is that it demands our academic critical practice to relate to the real world and concrete struggles. As academics, we can stand shoulder to shoulder with the activists, in an analectical solidarity and/or as co-militants, and we can use our privileged position to access the institutional publishing apparatus to fight the "battle of ideas" (GRAMSCI, 1971) at one key structure of the cultural circuits of capitalism (THRIFT, 2005).

To know is not to contemplate; it is not to reflect on the object's immediacy, it is mediation and a moment of transformation. Therefore, a Marxist ontology imposes the 
question of for whom and to what purpose knowledge is produced. This is not the same as the neo-illuminist critique that affirms that all knowledge is historical and social, while remaining prisoner of the centrality of the cognizant subject. Instead, it is a statement that the object's primacy is what indicates the theoretical content. However, it is necessary to say that the object is never pure particularity. All objects are, at the same time, singular and universal, as well as historically and socially determined. Therefore, this ontology interdicts the imposition of previously defined models of form/content or "a set of pre-packed answers" when studying SMs (COX, 2017, p. 16).

This is what we attempt to do in our militant academic praxis. The capacity to identify which enemies to fight against, and how they articulate among themselves, can only be achieved by comprehending the causal socioeconomic relations of the oppressive situation which people are submitted to in their everyday life. Therefore, the knowledge produced in these processes of struggles includes the explanation, from the perspective of the people, of how and why oppression is organized as it is. This is a movement that goes from their creative praxis to theory and back again.

The fact that OS are still dominated by the reified concept of organization is still an obstacle to the study of movements and their organizational practices. However, organization is a key concept for the study of SMs and we can provide a relevant contribution from within OS, if we keep in mind that, as Rauber (2003) argues, organizations that are built, by thought and action, in popular social struggles are mere political and social instruments and, at the same time, a component of the utmost importance. As instruments, these organizations can be ephemeral or more permanent, but by principle they will always be in movement.

The materialist ontology we have adopted here provides a means for further developments in this direction, because it demands the comprehension of the historical causes and the relations that make the existent what it is. This can be applied to any social complex and manifestations, ranging from policies to the law; from economic doctrines to different kinds of organizations and organizational processes. While considering "how the movement grows out of the material social relationships that shape people's lives" (COX, 2017, p. 5), it also provides a means of addressing the specificities of movements in parts of the world where the need to organize and struggle is a matter of survival.

This paper expresses the hope that with further engagements and dialogues we can explore the vast possibilities of knowledge production on the political question of the 
organization of social struggles, "reactivating the movement of thought and practice", as Lefebvre $(1969$, p. 8) wished, learning with the activists and valuing the changing realities of their organizational practices, specific histories and, sometimes, ephemeral existence.

\section{REFERENCES}

ALCOFF, L. An epistemology of the new revolution. Transmodernity, v. 1, n. 2, p. 67-78, 2011.

BAKKER, F.; DEN HOND, F., KING, B.; WEBER, K. Social movements, civil society and corporations: taking stock and looking ahead. Organization Studies, n. 34, v. 5-6, p. 573593, 2013.

BARKER, C.; COX, L.; KRINSKY, J.; NILSEN, A. Marxism and social movements: an introduction. In: BARKER, C.; COX, L.; KRINSKY, J.; NILSEN, A. (Eds.). Marxism and social movements. Leiden: Brill, 2013. p. 1-40.

BERTELS, S.; HOFFMAN, A. J.; DEJORDY, R. The varied work of challenger movements: identifying roles in US environmental movement. Organization Studies, v. 35, n. 8, p. 11711210, 2014.

BEVINGTON, D.; DIXON, C. Movement-relevant theory: rethinking social movement scholarship and activism. Social Movement Studies, v.4, n. 3, p. 185-208, 2005.

BLOCH, E. The principle of hope. Cambridge: The MIT Press, 1986.

BONEFELD, W. Uncertainty and social autonomy. The Commoner. 2004. Available at: http://www.commoner.org.uk/08bonefeld.pdf. Access: 11 Dec. 2019.

BONEFELD, W. Negative dialectics in miserable times: notes on Adorno and social praxis. Journal of Classical Sociology, v. 12, n.1, p. 122-132, 2012.

BOOKCHIN, N.; BROWN, P.; EBRAHIMIAN, S. et al. Militant research handbook. Available at: http://www.visualculturenow.org/wp-content/uploads/2013/09/MRH_Web.pdf. Accessed: 1 Jun. 2016 .

CHASIN, J. Rota e prospectiva de um projeto marxista [Route and prospective of a Marxist project]. Ad Hominem, n. 3, p. 5-78, 2000.

CLEMENS, E. S. Two kinds of stuff: the current encounter of social movements and organizations. In: DAVIS, G. F.; McADAM, D.; SCOTT, W. R.; ZALD, M. N. (Eds.) Social movements and organization theory. New York: Cambridge University Press, 2005. p. 351365.

CONTU, A. A political answer to questions of struggle. ephemera, v.2, n.2, p. 160-174, 2002 . 
CONTU, A.; PALPACUER, F.; BALAS, N. Multinational corporations' politics and resistance to plant shutdowns: A comparative case study in the south of France. Human Relations, v. 66, n. 3, p. 363-384, 2013.

COX, L. Movements making knowledge: a new wave of inspiration for sociology? Sociology, v. 48 , n. 5, p. 954-971, 2014.

COX, L. Learning to be loyal to each other: conversations, alliances, and arguments in the movement of movements. Afterword forthcoming in SEN, J. (Ed.) The movement of movements - Part 1: What makes us move? CA: PM Press, 2017.

COX, L.; FOMINAYA, C. F. European social movements and social theory: a reacher narrative? In: COX, L.; FOMINAYA, C. F. (Eds.). Understanding European movements, new social movements, global justice struggles, anti-austerity protest. London: Routledge, 2013. p. 7-19.

COX, L.; NILSEN, A. G. Social movements research and the "Movement of Movements": studying resistance to neoliberal globalization. Sociology Compass, v.1, n.2, p. 424-442, 2007.

COX, L.; NILSEN, A. G. We make our own history: Marxism and Social Movements in the twilight of neoliberalism. London: Pluto, 2014.

DEBORD, G. The decline and fall of the spectacle-commodity economy. 1965. Situationlist International. Available at: www.cddc.vt.edu/sionline/si/decline.html. Access: 11 Jan. 2017. DIANI, M. Networks and social movements: from metaphor to theory? In: Conference Social Movements Analysis: The Network Perspective, Loch Lomond, Scotland, 2000.

DUBUISSON-QUELLIER, S. A market mediation strategy: how social movements seek to change firms' practices by promoting new principles of product valuation. Organization Studies, v. 34, n. 5-6, p. 683-703, 2013.

DUAYER, M. Jorge Luis Borges, filosofia da ciência e crítica ontológica [Jorge Luis Borges, philosophy of science and ontological critique]. Revista Margem Esquerda, v. 24, n. 1, p. 86-110, 2015.

DUAYER, M.; MEDEIROS, J. L. Lukács' critical ontology and critical realism. Journal of Critical Realism, v. 4, n. 2, p. 395-425, 2005.

DUAYER, M.; MEDEIROS J.L. 'Under-labouring' for ethics: Lukács' critical ontology. In: Lawson C, Latsis $\mathrm{J}$ and Martins $\mathrm{N}$ (eds.) Contributions to social ontology. London: Routledge, pp. 102-124, 2007.

DUNAYEVSKAYA, R. Marxism and freedom: from 1976 until today. New Jersey: Humanities Press, 1982. 
DUNAYEVSKAYA, R. Philosophy and revolution: from Hegel do Sartre, from Marx to Mao. New York: Columbia University Press, 1989.

DUSSEL, E. Método para una filosofía de la liberación [Method for a philosophy of liberation]. Salamanca: Ediciones Sígueme, 1974.

DUSSEL, E. Hacia una filosofía política crítica [Towards a critical political philosophy]. Barcelona: Desclée de Brouwer, 2001.

FALS BORDA, O. El problema de cómo investigar la realidad para transformarla por la praxis [The problem of how to research reality to transform it through praxis]. In: FARFÁN, N. A. H.; GUZMÁN, L. (eds.) Ciencia, compromiso y cambio social: Orlando Fals Borda. Buenos Aires: El Colectivo, 2012. p. 213-240.

FERNÁNDEZ, J.; SEVILLA, C.; URBÁN, M. El topo quería tomar (el) sol [The mole wanted to sunbath]. In: FERNÁNDEZ, J.; SEVILLA, C.; URBÁN, M. (Eds.) ¡Ocupemos el mundo! Barcelona: Icaria, 2012. p. 13-26.

FLACKS, R. The question of relevance in social movements studies. In: CROTEAU, C.; HOYNES, W.: RYAN, C. (Eds.). Rhyming home and history: activists, academics and social movement scholarship. Minnesota: University of Minnesota Press, 20014. p. 3-19.

FREIRE, P. Pedagogy of the Oppressed. New York: The Continuum International Publishing Group, 2005.

GAMSON, W. A. Power and discontent. Homewood: Dorsey, 1968.

GOODWIN, J. J.; JASPER, J. Caught in a winding, snarling vine: the structural bias of political process theory. Sociological Forum, v.14, n. 1, p. 27-54, 1999.

GOODWIN, J. J. Social-Movement Studies today: an insider's (self-)critique. Available at: http://politicsandprotest.ws.gc.cuny.edu/files/2012/07/Goodwin-Contemporary-SociologyEssay.pdf. Access at: 11 Jan. 2018.

GRAMSCI, A. Selection from the Prison Notebooks. New York: International Publishers, 1971.

GRAMSCI, A. Cadernos do Cárcere I [Prison notebooks I]. Rio de Janeiro: Civilização Brasileira, 2006.

HARTMANN, N. New ways of ontology. Chicago: Enry Regnery, 1975.

HARVEY, D. Spaces of hope. Edinburgh: Edingurgh University Press, 2000.

HAUG, C. Organizing spaces: meeting arenas as social movement infrastructure between organization, network and institution. Organization Studies, v. 34, n. 5-6, p. 705-732, 2013.

HARDT, M.; NEGRI, A. Empire. Cambridge: Harvard University Press, 2000. 
HENSBY, A.; SIBTHORPE, J.; DRIVER, S. Resisting the 'protest business': bureaucracy, post-bureaucracy and active membership in social movements organization. Organization, $v$. 19, n. 6, p. 809-823, 2011.

KINCHELOE, J. L.: MCLAREN, P.: STEINBERG, S. R. Critical pedagogy and qualitative research: moving to the bricolage. In: DENZIN, N. K.; LINCOLN, Y. (Eds.) Handbook of qualitative research, $3^{\mathrm{a}}$ ed. London: Sage, 2011. p. 163-178.

LACLAU, E.; MOUFFE, C. Hegemony and socialist strategy. London: Verso, 2001.

LACLAU, E.; BASHKAR, R. Discourse Theory vs Critical Realism. Alethia, v.1, n.2, p. 914, 1998.

LEFEBVRE, H. The explosion: Marxism and the French upheaval. New York: Monthly Review Press, 1969.

LEFEBVRE, H. The urban revolution. Minneapolis: University of Minnesota Press, 2003.

LEFEBVRE, H. Critique of everyday life. London: Verso, 2014.

LUKÁCS, G. Marx’s basic ontological principles. London: Merlin Press, 1978a.

LUKÁCS, G. Labour. London: Merlin Press, 1978 b.

LUKÁCS, G. Para uma ontologia do ser social I [Ontology of social being I]. São Paulo: Boitempo, 2012.

LUKÁCS, G. Para uma ontologia do ser social II [Ontology of social being II]. São Paulo: Boitempo, 2013.

LUXEMBURG, R. The mass strike, the party, and the trade unions. In: HUDIS, P.; ANDERSON, B. (Eds.). The Rosa Luxemburg reader. New York: Monthly Review, 2004. p. 168-199.

MAECKELBERGH, M. Social movements and global governance. In: PARKER, M.; CHENEY, G.; FOURNIER, V.; LAND, C. (Eds.) The Routledge companion to alternative organization. New York: Routledge, 2014. p. 345-358.

MALO, M. Nociones Comunes: experiencias y ensayos entre investigación y militancia [Common notions: experiences and essays on research and activism]. Madrid: Traficantes de Sueños, 2004.

MARTÍN F. N. Marx de vuelta [Marx is back]. Buenos Aires: Editorial El Colectivo. 2014. McADAM, D.; McCARTHY, J. D.: ZALD, M. N. Introduction: opportunities, mobilizing structures, and framing processes - toward a synthetic, comparative perspective on social movements. In McADAM, D.; McCARTHY, J. D.: ZALD, M. N. (Eds.) Comparative perspectives on social movements: political opportunities, mobilizing structures, and cultural framings. New York: Cambridge University Press, 1966. p. 1-22. 
McADAM, D.; TARROW, S.; TILLY, C. Dynamics of contention. New York: Cambridge University Press, 2001.

McADAM, D.; SCOTT, W. R. Organizations and movements. In: DAVIS, G. F.; McADAM, D.; SCOTT, W. R.; ZALD, M. N. (Eds) Social movements and organization theory. New York: Cambridge University Press, 2005. p. 4-40.

McCARTHY, J. D.; ZALD, M. N. Resource mobilization and social movements: a partial theory. American Journal of Sociology, n. 82, p. 1212-1241, 1977.

MELUCCI, A. Nomads of the present: social movements and individual needs in contemporary society. Philadelphia: Temple University Press, 1989.

MISOCZKY, M. C.; FLORES, R. K.; SILVA, S. G. Estudos organizacionais e movimentos sociais: o que sabemos? Para onde vamos? [Organization studies and social movements: what do we know? Where are we going to?] Cadernos EBAPE.BR, v.6, n. 3, p. 1-14, 2008.

MORAES, J.; MISOCZKY, M. C. A organização dialógica do Movimento de Trabajadores Desocupados de La Matanza [The dialogical organization of unoccupied workers of La Matanza]. In: MISOCZKY, M. C.; FLORES, R. K.; MORAES, J. (Orgs.) Organização e práxis libertadora. Porto Alegre: Dacasa, 2010. p. 77-106.

MISOCZKY, M. C.; MORAES, J. Práticas organizacionais em escolas de movimentos sociais [Organizational practices in social movements schools]. Porto Alegre, RS: Dacasa, 2001.

NORRIS, C. Reclaiming truth: contribution to a critique of cultural relativism. Durham: Duke University Press, 1996.

NILSEN, A. G.; COX, L. What would a Marxist theory of social movements look like? In: BARKER, C. et al. (Eds) Marxism and social movements. Leiden: Brill, 2013. p. 63-81.

OLDRINI, G. (1999) Gramsci e Lukács, adversários do marxismo da Segunda Internacional [Gramsci and Lukács, adversaries of Second International Marxism]. Crítica Marxista, v. 8, n. 1, p. 67-80, 1999.

OLDRINI, G. (2013) Em busca das raízes da ontologia (marxista) de Lukács [In search of the (marxista) ontology roots of Lukács]. In: LUKÁCS, G. Para uma ontologia do ser social II. São Paulo: Boitempo, 2013. p. 9-36.

OLSON, M. The logic of collective action: public goods and the theory of groups. Cambridge: Harvard University Press, 1965.

OTTO, B.; BÖHM, S. "The people" and resistance against international business: The case of the Bolivian "water war". Critical Perspectives on International Business, v.2, n. 4, p. 299320, 2006.

PERROW, C. Organizational analysis: a sociological view. Belmont: Brooks/Cole, 1970. 
THOMPSON, M. J. Ontology and totality: reconstructing Lukács' concept of critical theory. In: THOMPSON, M. J. (Ed.) Georg Lukács reconsidered: critical essays in politics, philosophy and aesthetics. New York: Continuum, 2011. p. 229-249.

ÖZEN, S.; ÖZEN, H. Peasants against MNCs and the state: the role of the Bergama struggle in the institutional construction of the gold-mining field in Turkey. Organization, v. 16, n. 4, p. 547-573, 2009.

RAUBER, I. Movimientos sociales y representación política. [Social movements and political representation] Buenos Aires: Pasado y Presente XXI, 2003.

RAUBER, I. A transformação social en el siglo XXI: camino de reformas o de revolución [Social transformation in XXI century: reform or revolution paths]. Pasado y Presente, n. 21, p. 1-26, 2004.

ROESCH, J. Spontaneity and organization. International Socialist Review, v. 85, n. 1 85(1), 2012. Available at: http://isreview.org/issue/85/spontaneity-and-organization. Access: 11 Jan. 2017.

ROMANO, S. M; DÍAS PARRA, I. Antipolíticas: neoliberalismo, realismo de izquierda y autonomismo en América Latina. Buenos Aires: Ed. Luxemburg/IEALC, 2018.

SÁNCHEZ VÁSQUEZ, A. The philosophy of praxis. Boston: Brill, 1977.

SCOTT, J. C. Weapons of the weak: everyday forms of peasant resistance. New Haven: Yale University Press, 1985.

SCOTT, J. C. Domination and the arts of resistance: hidden transcripts. New Haven: Yale University Press, 1990.

SITRIN, M. Horizontalidad: voces de poder popular [Horizontality: voices from popular power]. Buenos Aires: Chilavert, 2005.

SOULE, S. A. Social movements and markets, industries, and firms. Organization Studies, v. 33, n. 12, p. 1715-1733, 2012.

SMELSER, N. Theory of collective behavior. New York: Free Press, 1962.

SPICER, A.; BÖHM, S. Moving Management: Theorizing Struggles against the Hegemony of Management. Organization Studies, v. 28, n. 11, p. 1667-1698, 2007.

TARROW, S. Power in movement: social movements and contentious politics. New York: Cambridge University Press, 1998.

THOMPSON, M. J. Ontology and totality: reconstructing Lukács' concept of critical theory. In: THOMPSON, M. J. (Ed.). Georg Lukács reconsidered: critical essays in politics, philosophy and aesthetics. New York: Continuum, 2011. p. 229-249.

THRIFT, N. Knowing capitalism. London: Sage, 2005. 
TILLY, C. From mobilization to revolution. Reading: Addison-Wesley, 1978.

TILLY, C. Contentious performances. Cambridge, Cambridge University Press, 2008.

TILLY, C.; RULE, J. Measuring political upheaval. Princeton: Princeton University Press, 1965.

TOURAINE, A. Introduction to the study of social movements. Social Research, n. 52, p. 749-788, 1985.

VAISMAN, E.; FORTES, R. Politicality in the late thoughts of György Lukács. Revista de Estudos Políticos, v. 5, n. 1, p. 133-147, 2014.

VAN BOMMEL, K.; SPICER, A. Hail the snail: hegemonic struggles in the slow food movement. Organization Studies, v.32, n. 2, p. 1717-1744, 2011.

YAZIJI, M.; DOH, J. P. The role of ideological radicalism and resource homogeneity in social movement organization campaigns against corporations. Organization Studies, v. 34, n. 5-6, p. 755-780, 2013.

ZALD, M. N. Culture, ideology, and strategic framing. In: McADAM, D.; McCARTHY, J. D.: ZALD, M. N. (Eds.). Comparative perspectives on social movements: political opportunities, mobilizing structures, and cultural framings. New York: Cambridge University Press, 1966. p. 291-274.

ZALD, M. N.; ASH, R. Social Movement Organizations: growth, decay and change. Social Forces, n. 44, p. 327-341, 1966. 